\title{
Inhalt, Vol. 2, No. 3, 1979
}

\section{Contents}

Impressum Ill

Deutsche Krebshilfe e. V., Bonn

Aufbau und Ziele der Deutschen Krebshilfe 93

Wolnik, L. und Bauer, H., Marburg

Beitrag zur Epidemiologie des Ovarialkarzinoms 96

Dietrich, M, Hamburg; Abt, C; Arnold, R.;

Pflieger, H.; Hoelzer, D.; Kurrle, E.; Rasche, H.;

Kubanek, B.; Heimpel, H. und Fliedner, T. M., Ulm

Die Wirksamkeit gnotobiotischer Maßnahmen bei der

Behandlung der akuten Leukämie: Ergebnisse einer

prospektiv randomisierten klinischen Studie 102

Fiedler, L.; Schlegel, G.; Kaiser, D. und

Zahradnik, H. P., Freiburg i. Br.

Untersuchungen zum perioperativen Verhalten von

Prostaglandin E2 (PGE2) und 13,14-dihydro-15-keto-

PGF $2 \alpha$ (DHK-PGF2 $\alpha$ ) im Serum beim Bronchialkarzinom 108

Hofer, H. O.; Nagel-Studer, E. und Nagel, G. A.,

Basel

Familiärer Morbus Hodgkin - Fallbericht und Literatur-

übersicht 113

Brühl, P.; Hoefer-Janker, H.; Scheef, W. und Vahlensieck, W., Bonn

Prophylaktische Alkalisierung des Harns bei zytostati-

scher Tumorbehandlung mit den Oxazaphosphorin-Deri-

vaten Cyclophosphamid und Ifosfamid

120

MÖHLEN, K. H. und Beller, F. K., Münster

Monochemotherapeutische Behandlung des fortge-

schrittenen Ovarialkarzinoms Stadium III und IV

Sonntag, R. W., Bern

Cis-Diaminodichloroplatin (II) - Eine neue Art von

Zytostatikum 129

Leserzuschriften 134

Buchbesprechungen 135

Imprint Ill

Deutsche Krebshilfe e. V., Bonn

Organisation and Aims of the Deutsche Krebshilfe .... 93

Wolnik, L. and Bauer, H., Marburg

On the Epidemiology of Cancer of the Ovary 
Dietrich, M., Hamburg; Abt, C; Arnold, R.;

Pflieger, H.; Hoelzer, D.; Kurrle, E.; Rasche, H.;

Kubanek, B.; Heimpel, H., and Fliedner, T. M., Ulm

Efficacy of Gnotobiotic Patient Care in Acute Leukemia

Treatment: Results of a Prospectively Randomised

Clinical Study 102

Fiedler, L.; Schlegel, G.; Kaiser, D., and Zahradnik, H. P., Freiburg i. Br.

On the Perioperative Behaviour of Prostaglandin E2

(PGE2) andl3,14-dihydro-15-keto-PGF2 $\alpha$ (DHK-PGF2 $\alpha$ )

in Serum in Bronchogenic Carcinoma 108

Hofer, H. O.; Nagel-Studer, E., and Nagel, G. A.,

Basel

Familial Hodgkin's Disease - Case Report and Literature

Survey 113

Brühl, P.; Hoefer-Janker, H.; Scheef, W., and Vahlensieck, W., Bonn

Prophylactic Alkalinization of Urine in Cytostatic Tumor

Therapy with the Oxazaphosphorine Derivates Cyclo-

phosphamide and Ifosf amide 120

Möhlen, K. H. and Beller, F. K., Münster

Monotherapeutic Treatment of Progredient Ovarian

Cancer Stage III and IV 126

Sonntag, R. W., Bern

Cis-Diamminedichloroplatinum (II) - A New Type of

Cytostatic Agent 129

Readers' Communications 134

Book Reviews 135

Bibliographischer Hinweis: Inhaltsverzeichnisse dieser Zeitschrift erscheinen regelmäßig in current contents ${ }^{\circledR}$ sowie in anderen bibliographischen Diensten. 